\title{
Genetic transformation of chickens using irradiated male gametes
}

\author{
N. Bumstead, \\ L. I. Messer, \\ B. M. Freeman and \\ A. C. C. Manning
}

\begin{abstract}
Houghton Poultry Research Station, Houghton,
\end{abstract} Huntingdon, Cambs. PE17 2DA, England.

\begin{abstract}
Results have been obtained which corroborate those of Pandey and Patchell (Molec. Gen. Genet., 186, 305, 1982) in demonstrating that genetic material from irradiated semen is incorporated into the embryo and expressed, albeit at rather a low rate, and is subsequently transmitted to progeny of the transfected birds. The method provides a technically straightforward means of transferring genetic material where rapid and reliable means of detecting the transferred gene exist. An advantage of the method is that regulatory regions are likely to be carried with the transferred gene but there is equally a disadvantage in the simultaneous transfer of unwanted material.
\end{abstract}

\section{INTRODUCTION}

Until recently the only means of introducing specific genes into a pure strain of animal has been by the lengthy process of repeated backcrossing coupled with selection for the gene being transferred. However, the successful insertion of the rat growth hormone gene into mice by Palmiter et al. (1982) and, more recently, into rabbits, sheep and pigs by Hammer et al. (1985), has demonstrated the potential for directly modifying the genetic constitution, at least in mammals. Unfortunately their technique of injecting DNA into a pronucleus at fertilisation would be much more difficult to apply in birds because of the far greater size of the ovum and because of its subsequent pattern of development. An alternative means of introducing genetic material has been reported by Pandey and Patchell (1982) who used heavily irradiated sperm, apparently to pseudofertilise the egg, prior to normal fertilisation by unirradiated semen. They obtained evidence for the incorporation of genes coding for egg or feather colour from the irradiated semen in 3.5 per cent of the progeny. This technique has the advantage of technical simplicity and reasonable rate of gene transfer, although with the drawback that the nature and extent of the material transferred is not controlled.

In view of the potential significance of this technique we have attempted to confirm the procedures of Pandey and Patchell (1982), using a slightly modified experimental design to avoid the two possible sources of error in an experiment of this nature-that the parent flocks were contaminated and that the supposedly lethally irradiated semen retained some capacity for fertilisation. Pandey and Patchell demonstrated that birds from their flocks not exposed to irradiated semen did not give rise to abnormal progeny, and that hens inseminated with irradiated semen produced no fertilised eggs. However, it was felt that as these points are crucial to the experiment it would be necessary to show that in the case of each apparently genetically transformed chick normal fertilisation had taken place and that the introduced genes were present in addition to the normal contribution from dam and unirradiated sire. The genes of the major histocompatibility complex (MHC) provide a convenient means to achieve this since matings can be arranged between homozygous parents carrying different haplotypes, and birds carrying a third MHC haplotype used to provide the irradiated semen. Thus normal progeny will be heterozygous, having the sire and dam haplotypes, while transformed progeny will carry three haplotypes, including that from the irradiated parent. By contrast chicks from eggs fertilised by irradiated sperm which had remained fertile would lack the haplotype of the normal sire; progeny from contaminants in the parental flocks would lack the haplotype of either the normal sire or of the dam. 
In nature chickens occur occasionally which are trisomic for the microchromosome bearing the MHC (Bloom et al., 1978; Plachy et al., 1979). In such birds all three MHC haplotypes are simultaneously expressed and it therefore seems reasonable to expect introduced $\mathrm{MHC}$ genes to be similarly co-expressed.

In addition to this primary marker a second, plumage colour, was also used. The crosses were between White Leghorn inbred lines, the plumage of which is consistently pure white, with Rhode Island males (coloured plumage) providing the irradiated semen. The progeny was therefore inspected for any abnormalities of plumage coloration. A limited number of birds were also analysed for their endogenous leukosis viral bands by Southern blotting to provide evidence of transfer directly at the molecular level.

\section{MATERIALS AND METHODS}

\section{Experimental design}

In order to provide a sufficient number of dams, two crosses between inbred lines of White Leghorns maintained at this institute were used. The dams were from the Wellcome line, which is homozygous for the $B^{14}$ haplotype, and from the $\mathrm{N}$ line, homozygous for the $B^{21}$ haplotype. The sires were from line $6_{1}$ for the Wellcome hens (homozygous for the $B^{2}$ haplotype) and from the Wellcome line for the $\mathrm{N}$ line hens. A group of six Rhode Island Red (RIR) males of known MHC haplotype were used as donors of semen which was to be irradiated. Four of these males were $B^{42} / B^{44}$ and two were $B^{42} / B^{42}$. Details of the matings and the possible blood groupings of the progeny are shown in table 1 . Further information on the lines may be found elsewhere (Report 198384).

\section{Insemination}

Semen was collected from males using a massage technique, pooled within any one strain and stored at room temperature until artificial insemination could be carried out. The samples from the RIR were exposed to $75 \mathrm{krad}$ of irradiation; the dose being delivered in about $17 \mathrm{~min}$. The total time, including transportation, was $2.5 \mathrm{~h}$ on average between collection and insemination.

Following the protocol of Pandey and Patchell (1982) birds were inseminated twice weekly (Mondays and Thursdays) with irradiated semen. The hens received normal semen on Tuesdays and Fridays. The volume inseminated was $20 \mu$ l per hen.

\section{Treatment of eggs and chicks}

The eggs were collected within a few hours of being laid and marked with details of the dam. They were stored for up to 7 days at $10-12^{\circ} \mathrm{C}$ and then incubated in a forced-air incubator at $38^{\circ} \mathrm{C}$. The hatched chicks were wing-banded and reared using conventional methods.

\section{Identification of MHC haplotypes}

The MHC phenotypes of the parents and chicks were determined by haemagglutination assay of red blood cells using alloantisera (Briles et al., 1980). Agglutination reactions were carried out in $U$-bottomed microtitre plates using $30 \mu l$ of diluted serum and an equal volume of fresh citrated blood diluted to 0.5 per cent cell volume in physiological buffered saline. Antisera were prepared by immunisations between birds of the HPRS set of MHC congenic lines, in which differing haplotypes have been backcrossed on to a common inbred background (line $6_{1}$ ). The titres of the antisera against the haplotypes used in the experiment are shown in table 2 . With the exception of the anti- $B^{44}$ serum (352) the antisera were monospecific in this context, even at high concentrations.

All birds in the parent flocks are routinely screened for their MHC haplotype each generation as a precaution against contamination, but all parent birds used in the experiment were additionally screened using all the antisera at four times

Table 1 Details of matings and possible progeny

$$
\begin{aligned}
& \text { Wellcome } q \times \text { Line } 6, B^{7} \\
& \left(B^{14} B^{14}\right) \quad\left(B^{2} B^{2}\right)
\end{aligned}
$$

$N$ Line $q \times$ Wellcome $\delta$

$\left(B^{21} B^{21}\right) \quad\left(B^{14} B^{14}\right)$

RIR $\&$ irradiated

$\left(B^{42} B^{44} ; B^{42} B^{42}\right)$
Normal

Transgenic

Fertile irradiated RIR semen

$B^{14} B^{2}$
$B^{14} B^{2} B^{42}: B^{14} B^{2} B^{44}$
$B^{14} B^{42} ; B^{14} B^{44}$

$B^{14} B^{2}$

$B^{14} B^{42} ; B^{14} B^{44}$
$B^{21} B^{14}$
$B^{21} B^{14} B^{42} ; B^{21} B^{14} B^{44}$
$B^{21} B^{42} ; B^{21} B^{44}$ 
Table 2 Titres of anti-MHC sera/haplotypes

\begin{tabular}{|c|c|c|c|c|c|}
\hline \multirow[b]{2}{*}{ Serum } & \multirow[b]{2}{*}{$B^{42} B^{42}$} & \multicolumn{3}{|c|}{ Reference haplotypes } & \multirow[b]{2}{*}{$B^{21} B^{21}$} \\
\hline & & $B^{44} B^{44}$ & $B^{2} B^{2}$ & $B^{14} B^{14}$ & \\
\hline 587 & 0 & 0 & $1 / 500$ & 0 & 0 \\
\hline 826 & 0 & 0 & 0 & 0 & $1 / 16$ \\
\hline 644 & 0 & 0 & 0 & $1 / 64$ & 0 \\
\hline 578 & $1 / 64$ & 0 & 0 & 0 & 0 \\
\hline 352 & 0 & $1 / 64$ & 0 & $1 / 4$ & 0 \\
\hline
\end{tabular}

the working strength. There were no unexpected reactions.

Progeny chicks were bled and their haplotypes determined at 3 weeks of age.

\section{Analysis of DNA}

DNA was extracted from $0.5 \mathrm{ml}$ heparinised blood by the method of Dodgson et al. (1979). Restriction enzyme digestions of $20 \mu \mathrm{g}$ genomic DNA were carried out using the enzyme Sst I or HindIII (BRL Ltd., Bethesda, Maryland, USA) and the appropriate enzyme buffer for $24 \mathrm{~h}$ at $37^{\circ} \mathrm{C}$. DNA was then precipitated in ethanol and pelleted in a microfuge. After washing the pellet with 70 per cent ethanol $(\mathrm{w} / \mathrm{v})$, it was vacuum dried and resuspended in $30 \mu \mathrm{l} \mathrm{T}$ : E solution ( $10 \mathrm{mM}$ Tris $\mathrm{HCl}, p \mathrm{H} 8 \cdot 0,1 \mathrm{mM}$ ethylene diaminotetraacetic acid (EDTA)). Five microlitres of loading buffer and dye (containing 0.25 per cent $(\mathrm{w} / \mathrm{v})$ bromophenol blue, 0.25 per cent $(\mathrm{w} / \mathrm{v})$ xylene cyanol and 30 per cent glycerol in $T: E$ ) were added to each sample and the DNA electrophoresed on an 0.6 per cent agarose gel $(\mathrm{w} / \mathrm{v})$ in $40 \mathrm{mM}$ Tris-acetate, $p \mathrm{H} 8 \cdot 0$, and $2 \mathrm{mM}$ EDTA, $p \mathrm{H} 8.0$ at $15 \mathrm{~V}$ for $48 \mathrm{~h}$ at room temperature. DNA was blotted on to nitrocellulose according to the Southern procedure (Southern, 1975) and then hybridised to an avian retroviral DNA probe nick-translated by the method of Rigby et al. (1977). This probe, pSRA-2, consisted of Rous sarcoma virus Schmidt-Ruppin strain cloned into the Sal site of PBR322 (DeLorbe et al., 1980). The hybridisation mixture contained 10 per cent dextran sulphate, $14 \mathrm{mM}$ Tris- $\mathrm{HCl}, p \mathrm{H}$ $7 \cdot 5,4 \times \mathrm{SSC}(0 \cdot 6 \mathrm{M} \mathrm{NaCl}, 0 \cdot 06 \mathrm{M}$ sodium citrate), 40 per cent deionised formamide, $50 \mu \mathrm{g} / \mathrm{ml}$ denatured salmon sperm DNA, $25 \mu \mathrm{g} / \mathrm{ml}$ yeast tRNA, and $0.8 \times$ Denhardt's solution $(0.016$ per cent polyvinyl pyrrolidone, 0.016 per cent Ficoll $400,0 \cdot 016$ per cent bovine serum albumin Pentax fraction $V$ ).

After incubation at $41^{\circ} \mathrm{C}$ for $48 \mathrm{~h}$, blots were washed three times for $30 \mathrm{~min}$ at room temperature in $2 \times \mathrm{SSC}, 0 \cdot 1$ per cent sodium dodecyl sulphate and 5 times for $20 \mathrm{~min}$ at $65^{\circ} \mathrm{C}$ in $0.1 \times \mathrm{SSC}$. The
Table 3 MHC phenotypes of progeny

\begin{tabular}{|c|c|c|c|c|}
\hline Hatch & $\begin{array}{l}\mathrm{N} \times \\
\text { Wellcome } \\
B^{21} B^{14}\end{array}$ & $\begin{array}{l}\text { Well come } \\
\times 6_{1} \\
B^{14} B^{2}\end{array}$ & Total & $\begin{array}{l}\text { Abnormal (Wing } \\
\text { band number*) }\end{array}$ \\
\hline 1 & 115 & 125 & 240 & 0 \\
\hline 2 & 127 & 128 & 255 & 0 \\
\hline 3 & 68 & 83 & 151 & 0 \\
\hline 4 & 153 & 78 & 231 & $1(857)$ \\
\hline 5 & 107 & 118 & 225 & $1(671)$ \\
\hline \multirow[t]{2}{*}{6} & 128 & 133 & 261 & $4(751,780,825,802)$ \\
\hline & 698 & 665 & 1363 & \\
\hline
\end{tabular}

* Phenotypes of abnormal progeny:

671: $B^{14}, B^{2}, B^{42}$

751: $B^{14}, B^{2}, B^{42}$

780: $B^{14}, B^{2}, B^{42}$

802: $B^{14}, B^{2}, B^{42}$

825: $B^{14}, B^{2}, B^{42}$

857: $B^{21}, B^{14}, B^{42}$

blots were wrapped in thin plastic film and exposed to Kodak XAR-5 film at $-70^{\circ} \mathrm{C}$ using two Dupont Cronex intensifying screens.

\section{RESULTS}

The results are summarised in table 3 . The six consecutive weekly hatches produced 1363 chicks. All these chicks carried the MHC haplotypes of both dam and unirradiated sire, confirming that the parent lines were not contaminated and that normal fertilisation by the unirradiated semen had taken place. However six of the progeny were found also to possess the RIR haplotype $B^{42}$.

All progeny birds were inspected for abnormal plumage patterns but all had typical plumage of White Leghorns.

It was reasoned that if the process of gene transfer were random, it was possible that other genetic markers could have been transferred at the same time as the MHC marker. Suitable markers for testing this hypothesis are the endogenous retroviral genes ( $e v$ loci) which have been integrated into the DNA of several chicken chromosomes in all unselected chicken lines (Rosenthal et al., 1971). The number of viral genes and site of integration of each endogenous virus into chicken DNA varies in different chicken lines (Astrin et al., 1979; Hughes et al., 1979; Humphries et al., 1984), although many chicken lines apparently share common ev loci. Chromosomal DNA containing viral genetic information would hybridise with a ${ }^{32}$ P-labelled retroviral DNA probe. Since 
the endogenous viral pattern of both parental chicken lines and the irradiated sperm donor cockerels could also be examined using restriction enzyme analysis and Southern blotting, it was decided to screen three of the six genetically transformed chicks, chosen at random, to determine whether specific endogenous viral genomes had originated from the irradiated sperm.

Fig. 1 shows the results from the three recombinant birds confirming, in each case, the presence of $e v$ loci which could have originated only from RIR irradiated sperm. Using the restriction enzyme Sst I to digest the DNA, and the plasmid DNA clone pSRA-2 as the retroviral probe, it was found that Wellcome, line $6_{1}$ and RIR possessed several ev loci, a number of which being common to all birds tested. There were, however, several loci which were found only in either the Wellcome or RIR birds. Line 6 , birds had very few loci, all of which were also present in either or both the Wellcome or RIR birds. The three recombinant birds $(671,751$ and 780$)$ possessed one band in common (fig. 1) which was also found in three of the irradi-

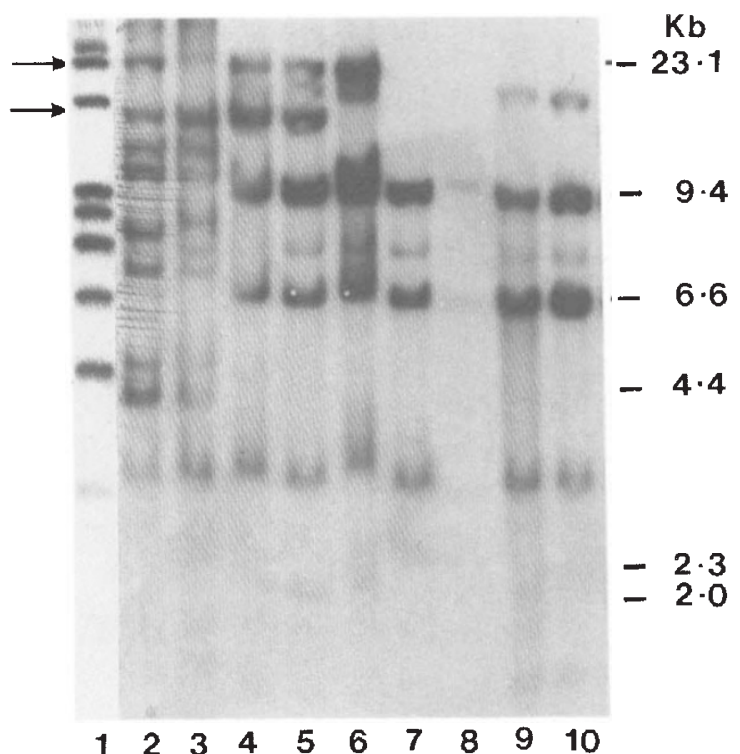

Figure $1 e v$ Loci lrom genomic DNA of parental and progeny birds. The DNA was extracted from red blood cells and digested with SstI. Details of the extraction procedure may be found in the Materials and Methods section. Arrows indicate bands present in the progeny and in the irradiated sperm donor birds (RIR) which were not present in either parent bird (line $\sigma_{1}$ and Wellcome). Band sizes (in kilobases) are indicated. The lanes are identified as follows: 1-3, RIR donors (irradiated semen); 4-6, Recombinant birds, wing band numbers 751,671 and 780 , respectively; 7 and 8 , line 6, sires; 9 and 10 , Wellcome line dams. ated sperm donors. A second additional band was also evident in two of the birds (671 and 751). These bands were absent from the DNA extracted from Wellcome or line 6 , chickens (indeed, they were absent in DNA extracted from all birds from the line $6_{1}$ or Wellcome flocks kept at HPRS: data not shown).

In order to test whether the transferred genes were stably inherited the transfected birds were mated to homozygous $B^{15}$ birds of the HPRS L15I flocks. A total of 98 chicks were produced and the MHC typed when 3 weeks old; 17 of these chicks were also typed for their ev loci.

Progeny from the bird which ceased to express the transfected phenotype (857) also did not express $B^{42}$. Progeny from the remaining birds segregated for $B^{42}$ as expected, however, in all cases the $B^{42}$ phenotype segregated with the $B^{2}$ haplotype. Progeny from control birds (which received irradiated semen but showed no effect) segregated for $B^{2}$ and $B^{14}$ as expected and were negative for $B^{42}$. These results are summarised in table 4.

Progeny from the three birds which showed extra, RIR derived, ev loci also segregated for these additional loci (table 5).

\section{DISCUSSION}

The results presented here confirm those of Pandey and Patchell (1982) in suggesting that, whether by pseudofertilisation or by another mechanism, genetic material from lethally irradiated sperm becomes incorporated into otherwise normally fertilised embryos. The presence of the haplotypes of both normal parents in addition to that from the irradiated sperm precludes the possibility that either a fraction of the irradiated sperm remained fertile or that the parental lines were contaminated or incorrectly mated.

Both the $B^{42}$ phenotype and the additional $e v$ loci of the transformed birds were transmitted to their progeny, confirming the stability of the transformation. The co-segregation of the $B^{42}$ marker with the $B^{2}$ haplotype is more surprising. This segregation excludes any possibility that the detecting antisera was reacting with a rare non$\mathrm{MHC}$ blood group present in the line 6 flock, since this would segregate independently of the $B^{2}$ haplotype. Conceivably homologous recombination may take place during the transfection; we are currently developing DNA probes for the MHC which will allow us to investigate this possibility at the molecular level. 
Table 4 MHC phenotypes of progeny of transfected birds

\begin{tabular}{llllll}
\hline \multicolumn{2}{l}{ Transfected parent } & \multicolumn{4}{l}{ Progeny phenotype } \\
\hline WB & Phenotype & 2.15 & 21.15 & 42.2 .15 & 4.21 .15 \\
857 & $21.2 .(42)^{*}$ & 8 & 8 & 0 & 0 \\
& & 2.15 & 14.15 & 42.2 .15 & 42.14 .15 \\
671 & 14.2 .42 & 0 & 9 & 5 & 0 \\
751 & 14.2 .42 & 0 & 15 & 9 & 0 \\
780 & 14.2 .42 & 0 & 13 & 12 & 0 \\
825 & 14.2 .42 & 0 & 6 & 7 & 0 \\
\hline
\end{tabular}

* Expression ceased before lay.

The absence of detectable effect on plumage colour is perhaps not surprising as our White Leghorn lines carry the characteristic dominant white $(\mathrm{I} / \mathrm{i})$ gene; heterozygous birds at this locus are virtually white, with rare dark flecks, it is not clear whether a transgenic I/I/i bird would show detectable colour variation.

Although Pandey and Patchell did report altered plumage pattern their White Leghorn flocks may not have carried the dominant white gene, or may have segregated at this locus.

The relatively low level of transfer of the marker gene compared with that found by Pandey and Patchell $(0.5$ per cent vs. 3.5 per cent $)$ and also compared with that of the unselected endogenous viral loci requires comment. The MHC haplotypes, as identified by the antisera, represent effectively single genes which have correspondingly a single chance of transfer. Plumage colour and egg colour, the markers used by Pandey and Patchell, are polygenic and would have a corresponding multiple chance of detection. Similarly the patterns of endogenous viral loci in the lines used made it possible to detect 10 loci. Other ev loci may have been donated but the co-migration of a number of viral DNA bands in all three chickens would make it difficult to be certain from which chicken the locus had originated. However, in the case of the viral bands the rate of transfer seems to have been much higher than this would account for. The presence of the same size DNA restriction band in all three birds suggests that the same endogenous viral gene had been donated. Additional data (not

Table 5 ev Loci of progeny of transfected birds

\begin{tabular}{lll}
\hline $\begin{array}{l}\text { Transfected } \\
\text { parent }\end{array}$ & Progeny \\
WB & No. tested & $\begin{array}{l}\text { Nowing } \\
\text { transferred ev locus }\end{array}$ \\
\hline 671 & 6 & 2 \\
751 & 6 & 4 \\
780 & 5 & 3
\end{tabular}

presented here), using the restriction enzyme HindIII supports this conclusion. It should be noted that this material may not have come from the same parent in each case.

It is possible that since we have detected these transferred viral bands in birds already known to have received MHC genes from the irradiated sperm this apparent high rate is due to a sufficiently large amount of DNA being transferred that both loci were included at once, an explanation which would imply a large part of the genome is transferred or that the $e v$ loci detected are linked to the MHC.

The latter explanation seems unlikely because in two birds (671 and 751) two distinct $e v$ loci were transferred, and because the transferred $e v$ loci did not co-segregate with the transferred MHC genes. Alternatively if the true rate of gene transfer were generally high, the infrequent level of detection of MHC products might have been due to the rate of expression of the transferred genes being low, especially since correct tissue expression is also required for the $\mathrm{MHC}$ gene products to be detected. This would not be represented in the detection of the viral genes at the DNA level, but would reduce the number of transgenics detected for the other markers which require expression of the proteins.

As a means of introducing foreign genetic information into flocks the amount of material transferred is critical to the method, since in the extreme case the results would be similar to conventional backcrossing, requiring the removal of the unwanted co-transferred material by backcrossing in the same manner. A corresponding advantage, however, would be the likely transfer of regulatory elements if large segments of DNA are indeed transferred, in contrast to other possible methods of transfer where these are likely to be lost.

It is evident that even at the highest likely rate of transfer only genes whose expression is fairly readily detectable would be suitable for transfer 
in a controlled manner, though the method could also be used in a blind manner akin to mutation breeding.

Acknowledgements The authors are indebted to Dr P. P. Dendy and his staff for allowing access to the radiation equipment of Addenbrookes Hospital, Cambridge. They acknowledge the skilled technical assistance of Mrs A. Jones and Messrs N. M. Greenwood, N. S. Salmon and I. H. Flack.

\section{REFERENCES}

ASTRIN, S. M., ROBINSON, H. L., CRITTENDEN, I. B., BUSS, E. G., WYBAN, J. AND HAYWARD, w. S. 1979. Ten genetic loci in the chicken that contain structural genes for endogenous virus. Cold Spring Harbor Symp. Quant. Biol., 44, 1105-1109.

BLOOM, S. E., COLE, R. K. AND BACON, L. D. 1978. Chromosomal localization of the major histocompatibility $(B)$ locus in the chicken. Poult. Sci., 57, 1119.

BRILES, W. E., BUMSTEAD, N., EWART, D. L., GILMOUR, D. G., GOGUSEV, J., HALA, K., KOCH, C, LONGENECKER, B. M., NORIJSKOG, A. W., PINK, J. R. L., SCHIERMAN, L. W., SIMONSEN, M., TOIVANEN, A., TOIVANEN, P., VAINO, 0. AND WICK, G. 1982. Nomenclature for chicken major histocompatibility complex. Immunogenetics, 15, 441-447.

DELORBE, W. J., LUAW, P. A., GOODMAN, H. M., VARMUS, H. F. AND BISHOP, J. M. 1980. Molecular cloning and characterization of avian sarcoma virus circular DNA molecules. J. Virol., 36, 50-61.

DODGSON, J. B., STROMMER, J. AND ENGEL, J. D. 1979. Isolation of the chicken $\beta$-globin gene and a linked embryonic $\beta$-like globin gene from a chicken DNA recombinant library. Cell, 17, 879-887.
HAMMER, R. E., PURSEL, V. G., REXROAD, (. E., WALL, R. I BOLT, D.J., EBERT, K. M., PALMITER, R. D. AND BRINSTER, R. L. 1985. Production of transgenic rabbits, sheep and pigs by microinjection. Nature, 315, 680-683.

HUGHES, S. H., PAYVAR, F., SPECTOR, D., SCHIMKE, R. T. ROBINSON, H. L., PAYNE, G. S., BISHOP, J. M. AND VAR MUS, H. E. 1979. Heterogeneity of genetic loci in chickens: analysis of endogenous viral and normal genes by cleavage of DNA with restriction endonucleases. Cell, 18, 347--359.

HUMPHRIES, E. H., DANHOF, M. L. AND HLOZANEK, I. 1984. Characterization of endogenous viral loci in five lines of White Leghorn chickens. Virology, 135, 125-138.

PALMITER, R. D., BRINSTER, R. L., HAMMER, R. E., TRUMBANE, M. I., ROSENFELD, M. G., BIRNBERG, N. C. AND EVANS, R. M. 1982. Dramatic growth of mice that develop from eggs microinjected with metallothionein-growth hormone fusion genes. Nature, 300, 611-615.

PANDFY, K. K., PATCHELL, M. R. 1982. Genetic transformation in chicken by the use of irradiated male gametes. Mol. Gen. Genet., 186, 305-308.

PLACHY, J., HALA, K. AND VIlHELMOVA, M. 1979. A spontaneous chicken chimaera with serologically and mor phologically different types of erythrocytes. Folia Biol. Praha, 25, 389-391.

REPORT (1983-84). Houghton Poultry Research Station, pp. 21-22.

RIGBY, P. W. J., DIECKMANN, M., RHODES, C. AND BERG, P. 1977. Labeling deoxyribonucleic acid to high specific activity in vitro by nick translation with DNA polymerase 1. J. Mol. Biol., 113, 237-251.

ROSENTHAL, P. N., ROBINSON, H. L., ROBINSON, W. S. HANAFUSA, T. AND HANAFUSA, H. 1971. DNA in uninfected and virus-infected cells complementary to avian tumor virus RNA. Proc. Natn. Acad. Sci., USA, 68, 2336-2340.

SOUTHERN, E. M. 1975. Detection of specific sequences among DNA fragments separated by gel electrophoresis. J. Mol. Biol., 98, 503-517. 